\title{
Marmoricola scoriae sp. nov., isolated from volcanic ash
}

\author{
Dong Wan Lee and Soon Dong Lee
}

Correspondence

Soon Dong Lee

sdlee@jejunu.ac.kr

\author{
Department of Science Education, Jeju National University, Jeju 690-756, Republic of Korea
}

The genus Marmoricola was proposed by Urzì et al. (2000) to accommodate an aerobic, Gram-positive, coccoid actinobacterium isolated from marble, Marmoricola aurantiacus, which was assigned to the family Nocardioidaceae on the basis of comparative 16S rRNA gene sequence analysis. Two other species in the genus, Marmoricola aequoreus (Lee, 2007) and Marmoricola bigeumensis (Dastager et al., 2008), were subsequently described, members of which were isolated from various environments such as marble, beach sediment and agricultural soil. The aim of the present study was to characterize a novel Gramstain-positive, coccoid actinobacterium, designated strain Sco-D $01^{\mathrm{T}}$, by using a polyphasic taxonomic approach. An emended description of the genus Marmoricola is also provided.

Strain Sco-D01 ${ }^{\mathrm{T}}$ was isolated from volcanic ash collected from Oreum (a parasitic volcanic cone) on Jeju Island, Republic of Korea. Volcanic ash samples (1 g) were ground into powder with a pestle and suspended in $10 \mathrm{ml}$ distilled water. Aliquots of serial dilutions were spread onto starchcasein agar ( $1 \%$ soluble starch, $0.03 \%$ casein, $0.2 \% \mathrm{KNO}_{3}$, $0.2 \% \mathrm{NaCl}, \quad 0.2 \% \mathrm{KH}_{2} \mathrm{PO}_{4}, \quad 0.002 \% \mathrm{CaCO}_{3}, \quad 0.005 \%$

Abbreviation: DAP, diaminopimelic acid.

The GenBank/EMBL/DDBJ accession number for the 16S rRNA gene sequence of strain Sco-D01 ${ }^{\top}$ is FN386750.

A supplementary table giving the cellular fatty acid profiles of strain $\mathrm{Sco}-\mathrm{DO} 1^{\top}$ and the type strains of recognized Marmoricola species is available with the online version of this paper.
$\mathrm{MgSO}_{4} \cdot 7 \mathrm{H}_{2} \mathrm{O}, \quad 0.001 \% \mathrm{FeSO}_{4} \cdot 7 \mathrm{H}_{2} \mathrm{O}$ and $1.8 \%$ agar; $\mathrm{pH}$ 7.2), and the plates were incubated at $30{ }^{\circ} \mathrm{C}$ for 2 weeks. A single colony was selected and further streaked on ISP (International Streptomyces Project) medium 2 (Shirling \& Gottlieb, 1966) at least three times. For phenotypic and genotypic comparisons, $M$. aurantiacus DSM $12652^{\mathrm{T}}$, M. aequoreus SST $-45^{\mathrm{T}}$ and M. bigeumensis KCTC $19287^{\mathrm{T}}$ were grown on R2A agar (Difco) for 5 days at $30{ }^{\circ} \mathrm{C}$.

Unless specified otherwise, the following morphological and physiological characteristics were investigated by using ISP 2 as the basal medium. The temperature and $\mathrm{pH}$ ranges for growth were determined at $4,10,20,30,37$ and $42{ }^{\circ} \mathrm{C}$ and at initial $\mathrm{pH}$ values of 4.1-12.1 (at intervals of $1.0 \mathrm{pH}$ units). $\mathrm{NaCl}$ tolerance for growth was tested on ISP 2 supplemented with 1-9\% (w/v) $\mathrm{NaCl}$. Gram staining, oxidase and catalase activities, degradation ability and utilization of carbohydrates were determined according to the methods described by Lee \& Lee (2008). Other physiological and biochemical properties were tested by using the API 20E and API ZYM kits (bioMérieux) according to the manufacturer's recommendations. Colony morphology and cell pigmentation were observed and recorded after incubation on ISP 2 for 5 days at $30{ }^{\circ} \mathrm{C}$. Cell morphology and motility were observed by using phase-contrast and transmission electron microscopy. For the latter, cells were stained with $1 \%$ phosphotungstic acid and observed with a model JEM-1200EX II (JEOL) transmission electron microscope. 
Cells of strain Sco-D01 ${ }^{\mathrm{T}}$ were aerobic, Gram-stain-positive, non-motile cocci $(0.6-1.0 \mu \mathrm{m}$ in diameter) that were present singly, in pairs or in clusters. Colonies were vivid yellow, circular, convex with entire margins and 0.1$0.2 \mathrm{~mm}$ in diameter after incubation on ISP 2 for 5 days at
$30{ }^{\circ} \mathrm{C}$. Other physiological and biochemical characteristics are given in Table 1 and in the species description below.

Extraction of genomic DNA and amplification and sequencing of the $16 \mathrm{~S}$ rRNA gene were performed as

Table 1. Characteristics that differentiate strain Sco-D01 ${ }^{\top}$ from the type strains of recognized Marmoricola species

Strains: 1 , Sco-D01 ${ }^{\mathrm{T}}$; 2, M. aequoreus SST-45 ${ }^{\mathrm{T}}$ (data from Lee, 2007); 3, M. aurantiacus DSM $12652^{\mathrm{T}}$ (Urzì et al., 2000); 4, M. bigeumensis MSL-0 $5^{\mathrm{T}}$ (Dastager et al., 2008). All were aerobic, Gram-positive, oxidase-negative and catalase-positive and hydrolysed aesculin. All were positive for enzyme activities of alkaline phosphatase, esterase lipase (C8), leucine arylamidase, $\alpha$-glucosidase and $\beta$-glucosidase, but negative for lipase (C14), $\alpha$ galactosidase, $\beta$-glucuronidase, $N$-acetyl- $\beta$-glucosaminidase, $\alpha$-mannosidase and $\alpha$-fucosidase (API ZYM). All were positive for $\beta$-galactosidase and the Voges-Proskauer reaction, but negative for arginine dihydrolase, lysine decarboxylase, ornithine decarboxylase, urease, tryptophan deaminase and indole production (API 20E). All utilized D-mannitol and methyl $\alpha$-D-glucoside as sole carbon source, but not formate, myo-inositol, methyl $\alpha$ D-mannoside or L-sorbose. +, Positive; -, negative; w, weakly positive; ND, not determined.

\begin{tabular}{|c|c|c|c|c|}
\hline Characteristic & 1 & 2 & $3^{*}$ & $4^{\star}$ \\
\hline Colony colour & Vivid yellow & Yellow & Orange & Lemon yellow \\
\hline Cell arrangement & Single, pairs or clusters & Single, pairs or clusters & Single, pairs or clusters & Single \\
\hline Temperature range $\left({ }^{\circ} \mathrm{C}\right)$ & $10-37$ & $10-37$ & $18-28$ & $20-37$ \\
\hline $\mathrm{NaCl}$ tolerance range $(\%)$ & $0-3.0$ & $0-7.0$ & $0.5-2.0$ & $0-7.0$ \\
\hline $\mathrm{pH}$ range & $6.1-12.1$ & $5.1-12.1$ & $5.1-8.7$ & $6.0-12.0$ \\
\hline Gelatin liquefaction & + & + & - & - \\
\hline \multicolumn{5}{|l|}{ Degradation of: } \\
\hline Casein & + & + & - & - \\
\hline DNA & + & ND & - & - \\
\hline Starch & - & - & - & + \\
\hline Xanthine & - & - & - & + \\
\hline Trypsin & $\mathrm{W}$ & - & - & + \\
\hline \multicolumn{5}{|l|}{ Utilization of (on ISP 9): } \\
\hline Adonitol & - & - & + & - \\
\hline D-Arabinose & + & - & + & - \\
\hline Citrate & + & + & + & - \\
\hline Dextran & - & + & + & + \\
\hline Glycerol & - & + & + & - \\
\hline D-Lactose & - & + & + & + \\
\hline Raffinose & + & - & + & - \\
\hline L-Rhamnose & + & - & + & + \\
\hline Salicin & + & - & + & - \\
\hline $\begin{array}{l}\text { DNA G }+ \text { C content } \\
(\mathrm{mol} \%)\end{array}$ & 72.0 & 72.4 & 72.0 & 72.9 \\
\hline Isolation source & Volcanic ash & Beach sediment & Marble & Agricultural soil \\
\hline
\end{tabular}

${ }^{*}$ Data for fatty acids and utilization of carbon sources are from the present study.

$\nmid$ DPG, Diphosphatidylglycerol; PC, phosphatidylcholine; PG, phosphatidylglycerol; PI, phosphatidylinositol; PL, unknown phospholipid. 
described by Lee \& Lee (2008). Multiple alignments of sequences were performed by using CLUSTAL $\mathrm{x}$ (Thompson et al., 1997). A phylogenetic tree was constructed by using the neighbour-joining method (Saitou \& Nei, 1987) and the model of Jukes \& Cantor (1969). The topology of the tree was assessed by performing bootstrap analysis of 1000 replicated neighbour-joining datasets (Felsenstein, 1985). An almost-complete 16S rRNA gene sequence (1425 nt) of strain Sco-D01 ${ }^{\mathrm{T}}$ determined in this study was compared with those of representatives of the family Nocardioidaceae. The phylogenetic tree (Fig. 1) revealed that strain Sco-D01 ${ }^{\mathrm{T}}$ belonged to the genus Marmoricola and formed a tight cluster with the type strain of M. aurantiacus (98.6\% 16S rRNA gene sequence similarity) that was supported by a
$93 \%$ bootstrap value. This topology was also recovered in trees generated with the maximum-likelihood (Fitch, 1971) and maximum-parsimony (Felsenstein, 1981) methods. The next closest phylogenetic neighbours of strain Sco$\mathrm{D} 01^{\mathrm{T}}$ were the type strains of $M$. aequoreus and $M$. bigeumensis (97.6 and $95.9 \%$ 16S rRNA gene sequence similarity, respectively).

Chemotaxonomic characteristics were investigated as described by Lee \& Lee (2008), with cell biomass obtained from a culture grown in ISP 2 broth for 5 days at $30{ }^{\circ} \mathrm{C}$. The following chemotaxonomic characteristics were determined by using standard methods: isomer of diaminopimelic acid (DAP) in the cell wall (Staneck \& Roberts,

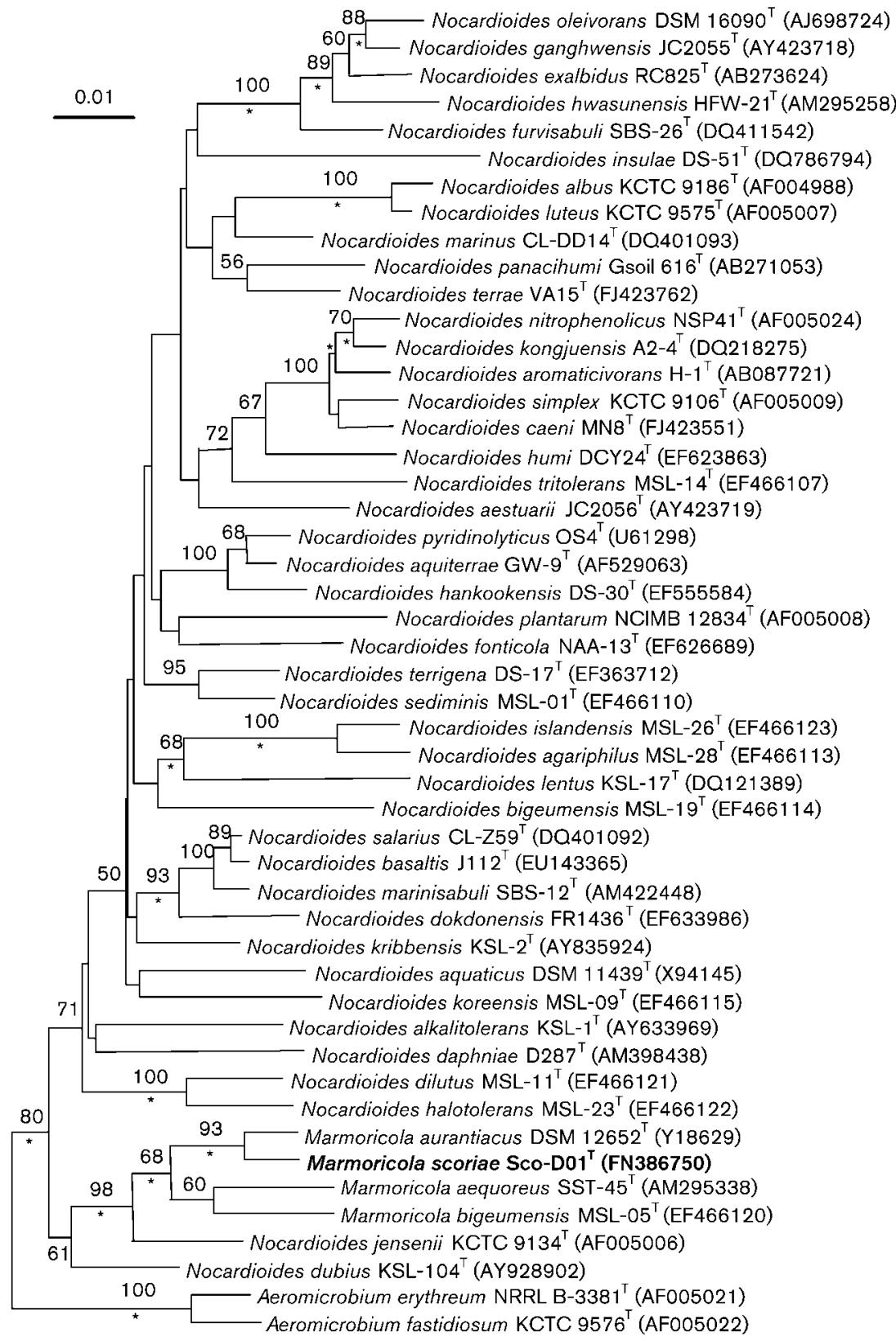

Fig. 1. Neighbour-joining tree based on $16 \mathrm{~S}$ rRNA gene sequences, showing the phylogenetic position of strain Sco-D01 ${ }^{\top}$ within the radiation of the family Nocardioidaceae. The sequence of Streptomyces griseus KCTC $9080^{\top}$ (GenBank accession no. M76388) served as the outgroup (not shown). Asterisks indicate branches that were also recovered in the maximum-likelihood and maximumparsimony trees. Bootstrap values (expressed as percentages of 1000 replications) of $\geqslant 50 \%$ are shown at nodes. Bar, 0.01 substitutions per nucleotide position. 
1974), respiratory quinones (Collins, 1985; Kroppenstedt, 1985), polar lipids (Minnikin et al., 1975) and DNA G + C content (Mesbah et al., 1989). For fatty acid analysis, strain Sco-D01 ${ }^{\mathrm{T}}$ and the type strains of the three recognized Marmoricola species were grown on R2A agar for 5 days at $30{ }^{\circ} \mathrm{C}$. Cellular fatty acid methyl esters were prepared and analysed according to the standard protocol of the Microbial Identification System (version 6; MIDI).

Strain Sco-D01 ${ }^{\mathrm{T}}$ contained LL-DAP as the diagnostic diamino acid in the cell-wall peptidoglycan. The predominant menaquinone was MK- $8\left(\mathrm{H}_{4}\right)$. The polar lipids comprised phosphatidylinositol, diphosphatidylglycerol, phosphatidylglycerol, phosphatidylcholine and an unknown phospholipid. The presence of phosphatidylcholine distinguishes strain Sco-D $01^{\mathrm{T}}$ from the type strains of recognized Marmoricola species, all of which lack this component in their polar lipid profiles. The DNA G $+\mathrm{C}$ content of strain Sco-D $01^{\mathrm{T}}$ was $72.0 \mathrm{~mol} \%$. The fatty acid profile of strain Sco-D $01^{\mathrm{T}}$ was characterized by large amounts of saturated and unsaturated components, together with moderate amounts of 10-methyl and hydroxyl fatty acids. The predominant fatty acids $\left(>10 \%\right.$ of the total) were $\mathrm{C}_{16: 0}$ $(27.7 \%), \mathrm{C}_{18: 1} \omega 9 c(25.9 \%)$ and 10 -methyl $\mathrm{C}_{18: 0}(10.2 \%)$. Strain Sco-D01 ${ }^{\mathrm{T}}$ could be differentiated from the type strains of $M$. aequoreus and $M$. aurantiacus based on the presence/absence of iso- $\mathrm{C}_{16: 0}, \mathrm{C}_{17: 1} \omega 6 c, \mathrm{C}_{17: 0} 2-\mathrm{OH}$ and anteiso- $\mathrm{C}_{19: 0}$, and could be distinguished easily from the type strain of $M$. bigeumensis based on the relative amounts of the major components $\left(\mathrm{C}_{16: 0}\right.$, iso- $\mathrm{C}_{16: 0}, \mathrm{C}_{18: 1} \omega 9 c$ and 10-methyl $\mathrm{C}_{18: 0}$ ). The cellular fatty acid profiles of strain Sco-D $01^{\mathrm{T}}$ and the type strains of recognized Marmoricola species are given in Supplementary Table S1, available in IJSEM Online.

DNA-DNA hybridization experiments were performed by using the method of De Ley et al. (1970) with the modifications described by Huß et al. (1983). The level of DNA-DNA relatedness between strain Sco-D01 ${ }^{\mathrm{T}}$ and $M$. aurantiacus DSM $12652^{\mathrm{T}}$ was $30.2 \%$ (35.4\% in duplicate measurements). Differential characteristics between strain Sco-D $01^{\mathrm{T}}$ and the type strains of $M$. aurantiacus, $M$. aequoreus and M. bigeumensis are detailed in Table 1 .

On the basis of phenotypic features and DNA-DNA hybridization data, strain Sco-D01 ${ }^{\mathrm{T}}$ is considered to represent a novel species of the genus Marmoricola, for which the name Marmoricola scoriae sp. nov. is proposed.

\section{Emended description of Marmoricola Urzì et al. 2000 emend Dastager et al. 2008}

Marmoricola (Mar.mo.ri'co.la. L. neut. n. marmor marble; L. masc. suffix -cola inhabitant of; N.L. masc. n. Marmoricola inhabitant of marble).

The description is as given by Urzì et al. (2000) and Dastager et al. (2008), with the following addition. Oxidase-negative and catalase-positive. Tuberculostearic acid (10-methyl $\mathrm{C}_{18: 0}$ ) and other branched fatty acids may be present. The presence of phosphatidylcholine is variable depending on species.

\section{Description of Marmoricola scoriae sp. nov.}

Marmoricola scoriae [sco.ri'ae. L. gen. n. scoriae of scoria (volcanic ash), referring to the site from which the type strain was isolated].

Cells are aerobic, Gram-stain-positive, oxidase-negative, catalase-positive, non-motile cocci $(0.6-1.0 \mu \mathrm{m}$ in diameter) that are present singly, in pairs or in clusters. Colonies are vivid yellow, circular, convex with entire margins and $0.1-0.2 \mathrm{~mm}$ in diameter after incubation on ISP 2 for 5 days at $30{ }^{\circ} \mathrm{C}$. Growth is observed at $\mathrm{pH}$ 6.112.1 (optimum at $\mathrm{pH} 8.1-11.1$ ), at $10-37{ }^{\circ} \mathrm{C}$ (optimum at $30{ }^{\circ} \mathrm{C}$ ) and in the presence of $0-3 \%(\mathrm{w} / \mathrm{v}) \mathrm{NaCl}$ (optimum at $0 \% \mathrm{NaCl}) . \mathrm{CM}$-cellulose, hypoxanthine, tyrosine and xanthine are not hydrolysed. $\mathrm{H}_{2} \mathrm{~S}$ production is not observed. Positive for enzyme activities of naphthol-ASBI-phosphohydrolase and valine arylamidase, but negative for activity of $\alpha$-chymotrypsin (API ZYM). Acetate, Larabinose, cellobiose, D-fructose, D-galactose, D-glucose, DL-malate, maltose, D-mannose, melezitose, L-ribose, sucrose, trehalose and D-xylose are utilized as sole carbon and energy sources, but benzoate, dulcitol, meso-erythritol and melibiose are not. Data for other physiological and biochemical properties are given in Table 1. LL-DAP is the diagnostic diamino acid in the cell-wall peptidoglycan. Polar lipids comprise phosphatidylinositol, diphosphatidylglycerol, phosphatidylglycerol, phosphatidylcholine and an unknown phospholipid. The predominant menaquinone is $\mathrm{MK}-8\left(\mathrm{H}_{4}\right)$. The major fatty acids are $\mathrm{C}_{16: 0}$, $\mathrm{C}_{18: 1} \omega 9 c$ and 10-methyl $\mathrm{C}_{18: 0}$. The DNA G $+\mathrm{C}$ content of the type strain is $72.0 \mathrm{~mol} \%$.

The type strain, Sco-D01 ${ }^{\mathrm{T}} \quad\left(=\mathrm{KCTC} \quad 19597^{\mathrm{T}}=\mathrm{DSM}\right.$ $22127^{\mathrm{T}}$ ), was isolated from volcanic ash of Oreum (a parasitic volcanic cone) in Jeju, Republic of Korea.

\section{Acknowledgements}

This study was supported by the 21C Frontier Microbial Genomics and Application Center Program, Ministry of Science and Technology, Republic of Korea. We thank Dr R. Pukall (Deutsche Sammlung von Mikroorganismen und Zellkulturen $\mathrm{GmbH}$ ) for providing the type strain of $M$. aurantiacus and Dr J.-S. Lee (Korean Collection for Type Cultures) for providing the type strain of $M$. bigeumensis.

\section{References}

Collins, M. D. (1985). Analysis of isoprenoid quinones. Methods Microbiol 18, 329-366.

Dastager, S. G., Lee, J.-C., Ju, Y.-J., Park, D.-J. \& Kim, C.-J. (2008). Marmoricola bigeumensis sp. nov., a member of the family Nocardioidaceae. Int J Syst Evol Microbiol 58, 1060-1063.

De Ley, J., Cattoir, H. \& Reynaerts, A. (1970). The quantitative measurement of DNA hybridization from renaturation rates. Eur $J$ Biochem 12, 133-142. 
Felsenstein, J. (1981). Evolutionary trees from DNA sequences: a maximum likelihood approach. J Mol Evol 17, 368-376.

Felsenstein, J. (1985). Confidence limits on phylogenies: an approach using the bootstrap. Evolution 39, 783-791.

Fitch, W. M. (1971). Towards defining the course of evolution: minimum change for a specific tree topology. Syst Zool 20, 406416.

Huß, V. A. R., Festl, H. \& Schleifer, K. H. (1983). Studies on the spectrophotometric determination of DNA hybridization from renaturation rates. Syst Appl Microbiol 4, 184-192.

Jukes, T. H. \& Cantor, C. R. (1969). Evolution of protein molecules. In Mammalian Protein Metabolism, pp. 21-132. Edited by H. N. Munro. New York: Academic Press.

Kroppenstedt, R. M. (1985). Fatty acid and menaquinone analysis of actinomycetes and related organisms. In Chemical Methods in Bacterial Systematics, pp. 173-199. Edited by M. Goodfellow \& D. E. Minnikin. London: Academic Press.

Lee, S. D. (2007). Marmoricola aequoreus sp. nov., a novel actinobacterium isolated from marine sediment. Int $J$ Syst Evol Microbiol 57, 1391-1395.

Lee, D. W. \& Lee, S. D. (2008). Aeromicrobium ponti sp. nov., isolated from seawater. Int J Syst Evol Microbiol 58, 987-991.
Mesbah, M., Premachandran, U. \& Whitman, W. B. (1989). Precise measurement of the $\mathrm{G}+\mathrm{C}$ content of deoxyribonucleic acid by highperformance liquid chromatography. Int J Syst Bacteriol 39, 159-167.

Minnikin, D. E., Alshamaony, L. \& Goodfellow, M. (1975). Differentiation of Mycobacterium, Nocardia, and related taxa by thin layer chromatographic analysis of whole-cell methanolysates. J Gen Microbiol 88, 200-204.

Saitou, N. \& Nei, M. (1987). The neighbor-joining method: a new method for reconstructing phylogenetic trees. Mol Biol Evol 4, 406-425.

Shirling, E. B. \& Gottlieb, D. (1966). Methods for characterization of Streptomyces species. Int J Syst Bacteriol 16, 313-340.

Staneck, J. L. \& Roberts, G. D. (1974). Simplified approach to identification of aerobic actinomycetes by thin-layer chromatography. Appl Microbiol 28, 226-231.

Thompson, J. D., Gibson, T. J., Plewniak, F., Jeanmougin, F. \& Higgins, D. G. (1997). The CLUSTAL_X windows interface: flexible strategies for multiple sequence alignment aided by quality analysis tools. Nucleic Acids Res 25, 4876-4882.

Urzì, C., Salamone, P., Schumann, P. \& Stackebrandt, E. (2000). Marmoricola aurantiacus gen. nov., sp. nov., a coccoid member of the family Nocardioidaceae isolated from a marble statue. Int J Syst Evol Microbiol 50, 529-536. 